\title{
Late Maastrichtian Calcareous Nannofossil Biostratigraphy and Paleoecology of the Tamera Well, Siwa Area, Western Desert, Egypt
}

\author{
Esam Zahran \\ Geology Department, Faculty of Science, Damanhour University, Damanhour, Egypt \\ Email: Zahran@yahoo.com
}

Received April 25, 2013; revised June 18, 2013; accepted July 15, 2013

Copyright (c) 2013 Esam Zahran. This is an open access article distributed under the Creative Commons Attribution License, which permits unrestricted use, distribution, and reproduction in any medium, provided the original work is properly cited.

\begin{abstract}
The upper Cretaceous interval of the Khoman Formation in the Tamera well, Siwa area, Western Desert of Egypt was studied for the first time on the basis of calcareous nannofossils. Twenty-one nannofossil species were identified from this interval. The study interval includes the Micula murus Zone, which is precisely dated as Late Maastrichtian age. The Micula murus Zone includes besides the marker species: Micula decussata, Watznaueria barnesae, Arkhangelsktella cymbiformis and relatively rare occurrences of Eiffellithus turrisieffellii, Cribrosphaerella ehrenbergii, Thoracosphaera operculata and Braarudosphaera bigelowii. The latest Maastrichtian Micula prinsi Zone is missing, and an unconformity surface is detected in this well. The high abundance of Micula decussata is indicative of very low surface productivity and high-stress environmental conditions. Several nannofossil species are recognized as cool water indicators such as Micula decussata, and Arkhangelsktella cymbiformis.
\end{abstract}

Keywords: Formation; Nannofossils; Micula Prins; Late Maastrichtian

\section{Introduction}

The Siwa Oasis is one of the series of depressions that lies in the shadow of the great Marmarica Plateau. It has an east-west direction with its center about $300 \mathrm{~km}$ south of the Mediterranean coast and approximately $65 \mathrm{~km}$ east of the Libyan border. To the north it is bounded by an escarpment which rises to about $100 \mathrm{~m}$ above the floor of the depression. To the south of the depression a sand dune belt exists trending in a northwest-southeast direction. The depression extends from Lake Zeitun in the east to Lake Maraqi in the west by a total length of $76 \mathrm{~km}$ and a maximum width of $20 \mathrm{~km}$. The Siwa area is approximately $980 \mathrm{~km}^{2}$. The lower parts of the depression floor average about 10 to $18 \mathrm{~m}$ below sea level.

The northern escarpment mainly trends in an east-west direction, but between longitudes $26^{\circ} 00^{\prime}$ and $26^{\circ} 30^{\prime}$, it extends southward for about $30 \mathrm{~km}$ into a promontory that forms the dividing highland between the Siwa and Qattara depressions.

The Siwa area was subjected to serve tectonic events due to its location in the Unstable Shelf area. From the Paleozoic until the Cenozoic, the area was subjected to faulting and many of the faults were being rejuvenated from time to time [1].

The study well is located in northwestern of the Siwa Oasis (Figure 1). The aim was to investigate and assign the calcareous nannofossils of the upper part of the Khoman Formation (Maastrichtian) in the subsurface rocks of the Western Desert of Egypt.

\section{Stratigraphy}

The Cretaceous-Tertiary sedimentary succession, in the studied well at Siwa Oasis, is generally subdivided into seven lithostratigraphic units; three of them are related to the Neogene, namely Marmarica Formation (Middle Miocene), Mamura Formation (Lower Miocene) and Apollonia Formation (Paleocene-Middle Eocene); and the rest to the Cretaceous, namely Khoman (Chalk) Formation (Campanian-Maastrichtian), Abu Roash Formation (Turonian), Bahariya Formation (Cenomanian) and Burg El Arab Formation (Early Cretaceous). The Khoman Formation consists of chalky limestone, partly argillaceous, with few chert bands and containing few sand streaks at the base. The chalky limestone points to open marine sedimentation as a result to Upper Cretaceous marine transgression [2]. 


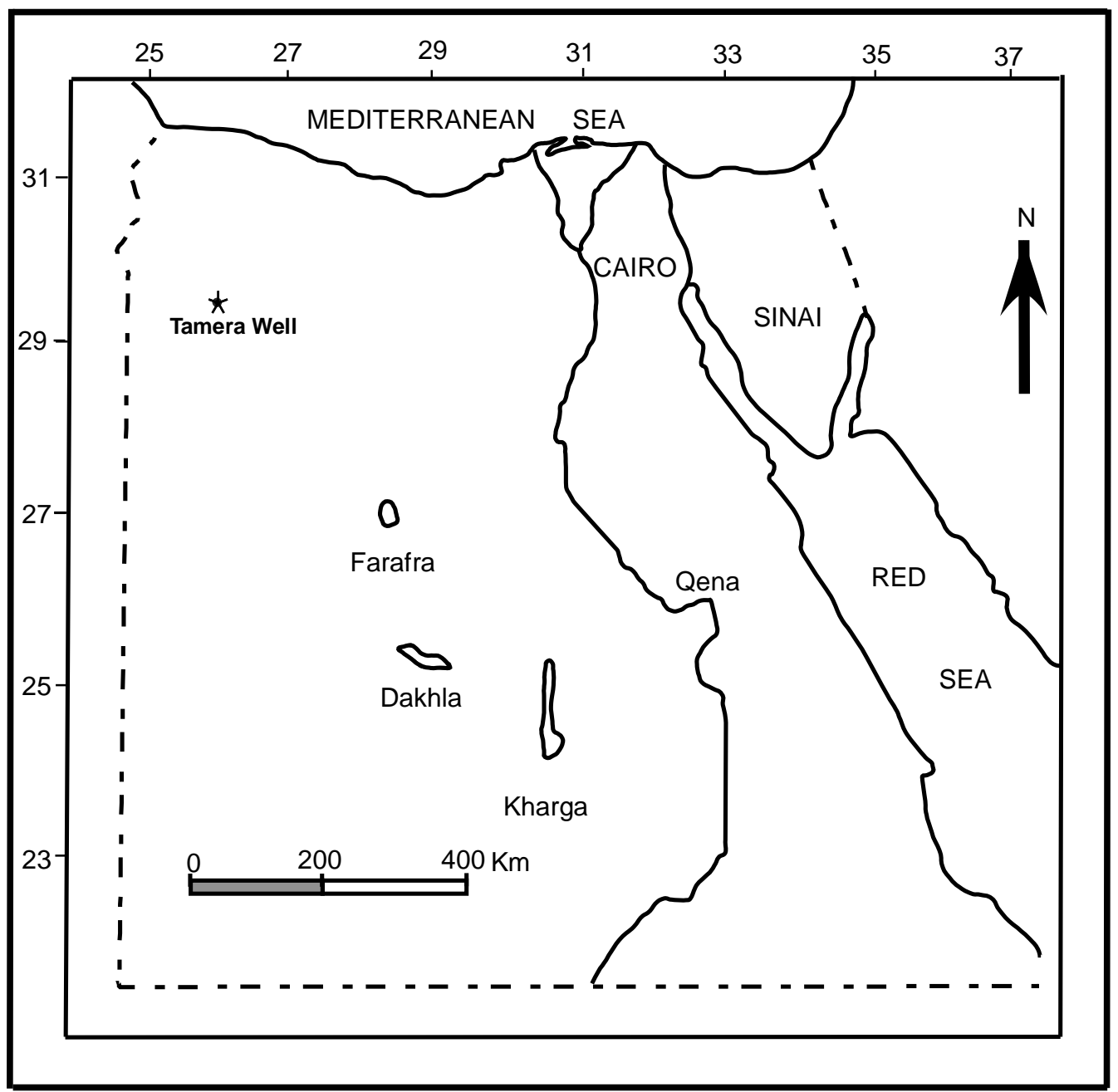

Figure 1. Location map of Tamera Well, Siwa Basin, Western Desert, Egypt.

In the southern part of the Siwa area, the Khoman Chalk is unconformably underlain by the Turonian rocks of the Abu Roash Formation that composed of coarse grained, subangular, fairly sorted sandstone. At Siwa Oasis, the formation is built up typically of limestone and dolomite. The limestone is finely crystalline, highly fractured, partly vuggy, and occasionally with calcite crystals in cavities.

In the north and northeastern parts of the Siwa area, the Khoman Formation is composed of soft and slightly calcareous shale that intercalated with argillaceous limestone. In such areas, the lithology reflects a near-shore to very shallow shelf environment, with a subsequent efficient fresh-water circulation [2].

In the study well, the upper part of the Khoman Formation consists mainly of shales, shaly limestone, and sandstone with shale intercalations (Figure 2).

\section{Material and Methodology}

A total of 56 samples were obtained from the upper part of the Khoman Formation of the Tamera well that located in the northwestern part of the Siwa area, Western Desert, Egypt. The samples were studied for their calcareous nannofossils. The relative abundances of the calcareous nannofossils were estimated from simple smearslides following the methodology described in [3]. These slides were viewed at $1250 \times$ magnification, using an oil immersion objective lens on an Olympus light-microscope that equipped with automatic camera.

The relative abundances of the species were estimated over three traverses of each slide. The abbreviations used in this study are: few $(\mathrm{F}=20$ - 40 specimens), rare $(\mathrm{R}=$ $10-20$ specimens), and very rare ( $\mathrm{VR}=<10$ specimens).

Preservation varies between moderate to poor: moderate $(\mathrm{M}=$ virtually all specimens are easily identifiable without secondary calcite overgrowth and/or calcite dissolution) and poor ( $\mathrm{P}=$ depleted assemblage due to calcite dissolution and/or an appreciable proportion of specimens are difficult to identify due to calcite dissolution or secondary overgrowth. 


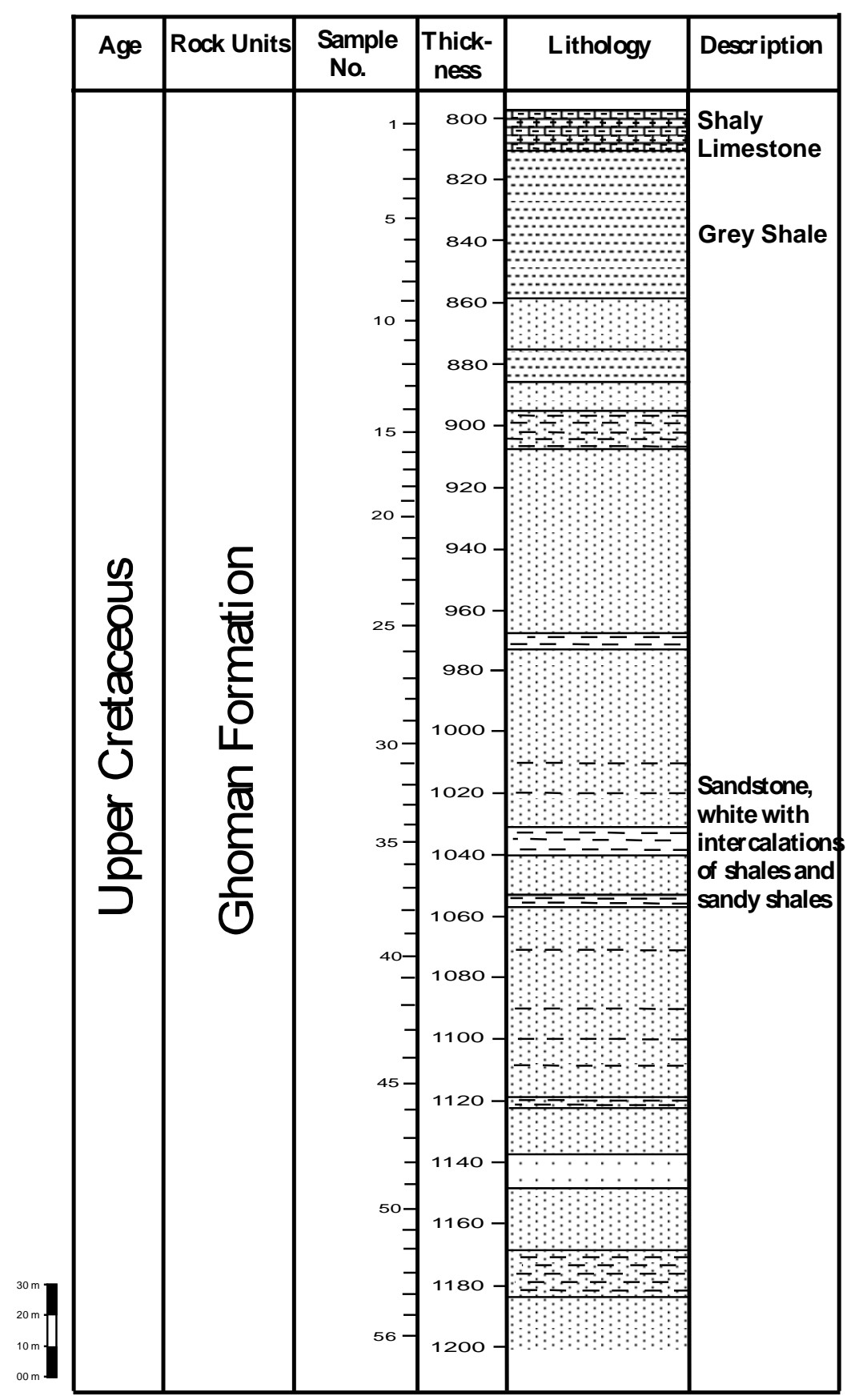

Figure 2. Stratigraphic section of Tamera Well, Siwa Basin, Western Desert, Egypt.

\section{Nannofossil Biostratigraphy}

In the present study, the biozonation scheme of [4], as modified by [5] was applied for the Maastrichtian sediments in the present study.

The distribution of the identified nannofossil taxa is shown in Figure 3, some representative nannofossil taxa are illustrated in Plates $\mathbf{1}$ and $\mathbf{2}$.

In the present study only one calcareous nannofossil biozone (Micula murus Zone) is identified. Details description of that zone is given in Figure 3.

\section{Micula murus Zone:}

The Micula murus Zone was proposed by [6] and modified by [7]. It is identified from the lowest occurrence (LO) of Micula murus to the LO of Micula prinsi.

It is worth mentioning that the latest Maastrichtian interval is missing due to the absence of the calcareous nannofossil Micula prinsi Zone. The Micula murus Zone correlates with the lower part of the Nephrolithus frequens Zone [8] modified by [9] and the CC25c of [4]. [4] suggested a subdivision of CC25 Zone by the lowest 


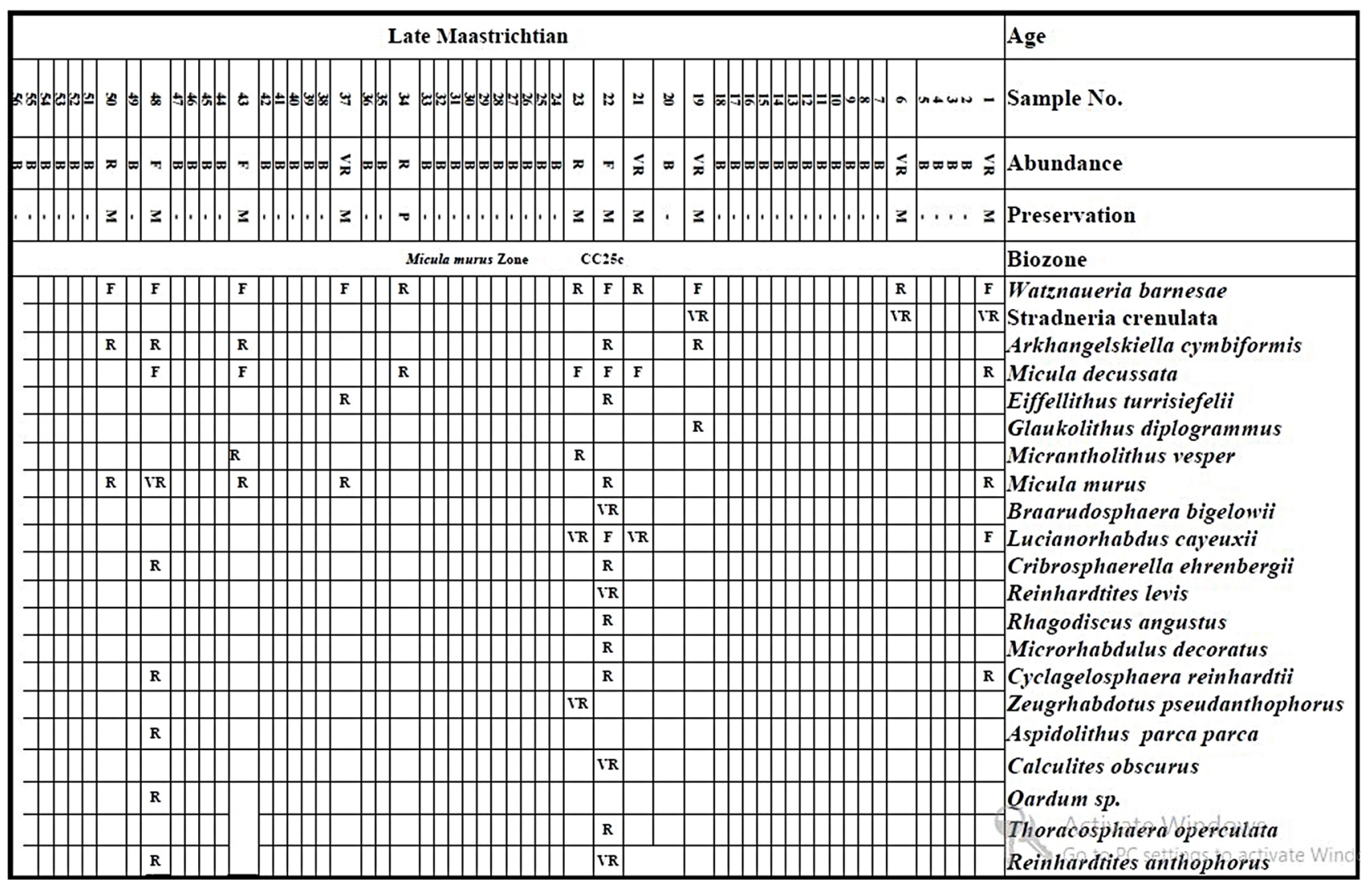

Figure 3. Distribution chart of the identified calcareous nannofossils in Tamera Well, Western Desert.

occurrence of A. cymbiformis and lowest occurrence of $L$. quadratus. Figure 4 shows a comparison between the used zonal scheme and that applied by [4]. This zone is dominated besides the marker species by Micula decussata, Watznaueria barnesae, Arkhangelsktella cymbiformis and relatively rare occurrences of Eiffellithus turrisieffellii, Cribrosphaerella ehrenbergii, Thoracosphaera operculata and Braarudosphaera bigelowii.

\section{Paleoecology}

The Micula decussata is a major component of the Late Cretaceous nannofossil assemblage. Few authors reported very high abundances of this species in well-preserved taxa from different paleoecological conditions from different parts of the world. Several authors suggested that this taxon might have preferred cooler temperatures [1012]. However, biogeographic studies of [10,13-16] showed that this taxon is clearly cosmopolitan and can reach as far as $80 \%$ in both tropical and sub-tropical assemblages. $[17,18]$ interpreted the high abundances of Micula decussata as indicative of very low surface productivity and high-stress environmental conditions.

Several nannofossil species are recognized as cool water indicators. These are mainly Arkhangelsktella cymbiformis, [10,13] referred Arkhangelsktella cymbiformis as a high-latitude taxon. However, [16] shows that this species is common down into tropical paleolatitudes, although it prefers high-latitudes.

Micula murus is clearly restricted to warm tropical waters and is totally absent from the high-latitude areas, all along its biostratigraphical range $[13,16,19,20]$. Thus, it could be considered as a good warm-water indicator.

Some nannofossil species are good indicators of surface water fertility. Watznaueria barnesiae is a cosmopolitan species which is generally dominant in tropical latitudes and only common in high-latitude sites. Thus, several authors used it as a warm-water indicator [11, 12,20]. However, several studies showed that Watznaueria barnesiae is mainly a low-nutrient indicator [21-25]. Other common taxa of Maastrichtian assemblages such as Cribrosphaerella ehrenbergii do not show any latitudinal preferences nor seem to be related to surface water fertility.

A summary of nannofossil temperature and fertility indices is presented in Table $\mathbf{1}$.

In the investigated samples of the present well, the dominance of cool water nannofossil assemblages (Micula decussata, and Arkhangelsktella cymbiformis) may indicate cooling conditions that prevailed during the deposition of the Khoman Formation. 


\begin{tabular}{|c|c|c|c|c|}
\hline Ag & & [4] & Bioevents & Present study \\
\hline \multirow{5}{*}{ Maastrichtian } & \multirow{4}{*}{ Late } & СC26 & $\begin{array}{l}\text { LO. } M . \text { prinsii } \\
\text { LO. } N \text {. frequens, C. kamptneri }\end{array}$ & Hiatus \\
\hline & & \multirow{3}{*}{ CC25 } & \multirow{3}{*}{$\begin{array}{l}\text { c-LO. M. murus } \\
\text { b-LO. L. quadratus } \\
\text { a-HO. R. Levis }\end{array}$} & \\
\hline & & & & Hiatus \\
\hline & & & & Hiatus \\
\hline & Middle & CC24 & HO. T. phacelosus, Q. trifidum & Hiatus \\
\hline
\end{tabular}

Figure 4. Maastrichtian calcareous nannofossil events in the studied well and that of [4]. (HO. Highest Occurrences, LO. Lowest Occurrences).

Table 1. Calcareous nannofossil paleoecological indices considered in this study (compiled from different sources).

\begin{tabular}{|c|c|c|c|}
\hline \multicolumn{2}{|c|}{ Fertility indices } & \multicolumn{2}{|c|}{ Temperature indices } \\
\hline High-fertility taxa & not detected & Cool water taxa & Arkhangelsktella cymbiformis \\
\hline Mid-fertility taxa & $\begin{array}{c}\text { not detected } \\
\text { Watznaueria } \text { barnesiae }\end{array}$ & Warm-water taxa & Micula murus \& Watznaueria barnesiae \\
\hline
\end{tabular}

\section{Discussion and Conclusions}

This study is considered the first attempt to study the nannofossil taxa of the Khoman Formation in the Tamera well, Western Desert of Egypt. Twenty-one nannofossil species have been identified in this study. The study interval (the upper part of the Khoman Formation) includes the Micula murus Zone, which is precisely dated by means of its calcareous nannofossils as Late Maastrichtian age. The Micula prinsi Zone of the latest Maastrichtian age is missed in the study well.

The Watznaueria barnesiae and Micula decussata are considered as two high solution-resistant species and are generally used to test the preservation degree of the assemblage [26,27].

Throughout the Cretaceous, the Watznaueria barnesiae is rare to frequent in the study samples and considered to be a eurytopic cosmopolitan species as previously mentioned by [28-30].

In the present core samples, the dissolution resistsnt Watznaueria barnesae is rare to frequent and it is considered to be a good index taxon to indicate alteration of the assemblages.

Watznaueria barnesae seems to also be more characteristic of low-mid latitude areas, being rare in high-latitude sites.

It is probable that differing paleoceanographic conditions (i.e. paleotemperature, paleosalinity, fertility fluctuations) affected the relative abundant of Watznaueria barnesae.

On the other hand, the distribution of Watznaueria barnesiae seems to be a good indicator of surface water fertility changes and recently have been used as nannofossil fertility index [31,32]. During the Maastrichtian, this species is generally rare or absent from high-latitude assemblages [33-35]. Moreover, it seems that temperature might also have played a significant role in the dis- tribution of this taxon (Watznaueria barnesiae).

The Micula murus is a rare component of the Maastrichtian calcareous nannofossil assemblages in the study well. The dominance of cold nannossil assemblages in the studied upper Maastrichtian interval may suggest cool surface water paleotemperature during this time.

\section{REFERENCES}

[1] R., Said, “The Geology of Egypt,” Elsevier, Amsterdam, New York, 1962, 377p.

[2] R. Said, “The Geology of Egypt,” Egypt. G.P.C., Conoco and Rep. Exple., Balkema, Rotterdam, Brookfield, 1990, $734 \mathrm{pp}$.

[3] P. R. Bown and J. R. Young, “Techniques,” In: P. R. Bown, Ed., Calcareous Nannofossil Biostratigraphy (British Micropaleontological Society Series), Chaman and Hall/ Kluwer Academic Publishers, London, 1998, pp. 16-28.

[4] W. Sissingh, "Biostratigraphy of Cretaceous Calcareous Nannoplankton,” Geologie en Mijnbouw, Vol. 56, No. 1, 1977, pp. 37-65.

[5] K. Perch-Nielsen, "Mesozoic Calcareous Nannofossils," In: H. M. Bolli, J. B. Saunders and K. Perch-Nielsen, Eds., Plankton Stratigraphy, Cambridge University Press, Cambridge, 1985, pp. 329-426.

[6] D. Bukry and M. N. Bramlette, "Coccolith Age Determinations,” Leg 3, Initial Report of DSDP 3, 1970, pp. 589-611.

[7] K. Perch-Nielsen, "New Maastrichtian and Paleocene Calcareous Nannofossils from Africa, Denmark, the USA and the Atlantic and some Paleocene Lineages," Eclogae Geologicae Helvetiae, Vol. 74, 1981, pp. 7-23.

[8] P. Cepek and W. W. Hay, "Calcareous Nannoplankton and Biostratigraphic Subdivisions of the Upper Cretaceous," Gulf Coast Association of Geological Societies Transactions, Vol. 19, 1969, pp. 323-336.

[9] A. J. T. Romein, "Lineages in the Early Paleogene Calcareous Nannoplankton,” State University of Utrecht, 
Utrecht, 1979, 231p.

[10] F. H. Wind, "Maestrichtian-Campanian Nannofloral Provinces of the Southern Atlantic and Indian Oceans,” In: M. Talwani, W. W. Hay and W. B. F. Ryan, Eds., Deep Drilling Results in the Atlantic Ocean: Continental Margins and Paleoenvironment, American Geophysical Union (AGU), Washington DC, 1979, pp. 123-137.

[11] P. H. Doeven, "Cretaceous Nannofossil Stratigraphy and Paleocology of the Canadian Atlantic Margin," Geological Survey of Canada, Vancouver, 1983, 69p.

[12] D. K. Watkins and J. M. Self-Trail, "Calcareous Nannofossil Evidence for the Existence of the Gulf Stream during the Late Maastrichtian,” Paleoceanography, Vol. 20, 2005, 9p. doi:10.1029/2004PA001121

[13] H. R. Thierstein, "Late Cretaceous Nannoplankton and the Change at the Cretaceous-Tertiary Boundary,” In: J. E. Warme, R. G. Douglas and E. L. Winterer, Eds., The Deep Sea Drilling Project: A Decade of Progress, Special Publications of SEPM, The Society of Economic Paleontologists and Mineralogists, Tulsa, 1981, pp. 355-394.

[14] S. Shafik, "Late Cretaceous Nannofossil Biostratigraphy and Biogeography of the Australian Western Margin," Australian Government Publishing Service, 1990

[15] A. S. Henriksson and B. A. Malmgren, "Biogeographic and Ecologic Patterns in Calcareous Nannoplankton in the Atlantic and Pacific Oceans during the Terminal Cretaceous,” Studia Geologica Salmanticensia, Vol. 33, 1997, $17-40$.

[16] J. A. Lees, “Calcareous Nannofossils Biogeography Illustrates Palaeoclimate Change in the Late Cretaceous Indian Ocean,” Cretaceous Research, Vol. 23, No. 5, 2002, pp. 537-634. doi:10.1006/cres.2003.1021

[17] Y. Eshet, S. Moshkovitz, D. Habib, C. Benjamini and M. Margaritz, "Calcareous Nannofossil and Dinoflagellate Stratigraphy across the Cretaceous/Tertiary Boundary at Hor Hahar, Israel,” Marine Micropaleontology, Vol. 18, No. 3, 1992, pp. 199-228. doi:10.1016/0377-8398(92)90013-A

[18] A. A. A. M. Tantawy, "Calcareous Nannofossil Biostratigraphy and Palaeoecology of the Cretaceous-Tertiary Transition in the Central Eastern Desert of Egypt," Marine Micropaleontology, Vol. 47, No. 3-4, 2003, pp. 323356. doi:10.1016/S0377-8398(02)00135-4

[19] T. Worsley and E. Martini, "Late Maastrichtian Nannoplankton Provinces," Nature, Vol. 225, 1970, pp. 12421243. doi:10.1038/2251242b0

[20] D. K. Watkins Jr., S. W. Wise, J. J. Pospichal and J. Crux, "Upper Cretaceous Calcareous Nannofossil Biostratigraphy and Paleoceanography of the Southern Ocean,” In: A. Moguilevsky and R. Whatley, Eds., Microfossils and Oceanic Environments, University of Wales-Aberstyweth Press, Aberystwyth, 1996, pp. 355-381.

[21] P. H. Roth and K. R. Krumbach, "Middle Cretaceous Nannofossil Biogeography and Preservation in the Atlantic and Indian Oceans: Implications for Palaeoceanography,” Marine Micropaleontology, Vol. 10, No. 1-3, 1986, pp. 235-266. doi:10.1016/0377-8398(86)90031-9

[22] E. Erba, F. Castradori, G. Guasti and M. Ripepe, “Calcareous Nannofossils and Milankovitch Cycles: The Ex- ample of the Gault Clay Formation (Southern England)," Palaeogeography, Palaeoclimatology, Palaeoecology, Vol. 93, No. 1-2, 1992, pp. 47-69. doi:10.1016/0031-0182(92)90183-6

[23] M. A. Lamolda, A. Gorostidi and R. C. Paul, "Quantitative Estimates of Calcareous Nannofossil Changes across the Plenus Marls (Latest Cenomanian), Dover, England: Implications for the Generation of the Cenomanian-Turonian Boundary Event,” Cretaceous Research, Vol. 15, 1992, pp. 143-164.

[24] J. R. Williams and T. J. Bralower, "Nannofossil Assemblages, Finefraction Stable Isotopes, and the Paleoceanography of the Valanginian-Barremian (Early Cretaceous) North Sea Basin,” Paleoceanography, Vol. 10, No. 4, 1995, pp. 815-839. doi:10.1029/95PA00977

[25] C. G. Fisher and W. W. Hay, "Calcareous Nannofossils as Indicators of Mid-Cretaceous Paleofertility along an Ocean Front, U.S. Western Interior,” In: E. Barrera and C. C. Johnson, Eds., Evolution of the Cretaceous OceanClimate System, Geological Society of America, Boulder, 1999, pp. 161-180.

[26] M. E. Hill, "Selective Dissolution of Mid-Cretaceous (Cenomanian) Calcareous Nannofossils," Micropaleontology, Vol. 21, No. 2, 1975, pp. 227-235. doi:10.2307/1485025

[27] H. R. Thierstein, "Selective Dissolution of Late Cretaceous and Earliest Tertiary Calcareous Nannofossils: Experimental Evidence,” Cretaceous Research, Vol. 1, No. 2, 1980, pp. 165-176. doi:10.1016/0195-6671(80)90023-3

[28] J. Mutterlose, "Das Verteilungs-und Migrationsmuster des Kalkigen Nannoplanktons in der Borealen Unterkreide (Valangin-Apt) NW-Deutschlands,” Palaeontographica, Vol. B221, 1991, pp. 27-152.

[29] J. Mutterlose and K. Kessels, "Early Cretaceous Calcareous Nannofossils from High Latitudes: Implications for Palaeobiogeography and Palaeoclimate," Palaeogeography, Palaeoclimatology, Palaeoecology, Vol. 160, No. 3-4, 2000, pp. 347-372. doi:10.1016/S0031-0182(00)00082-1

[30] M. Melinte and J. Mutterlose, “A Valanginian (Early Cretaceous) 'Boreal Nannoplankton Excursion' in Sections from Romania,” Marine Micropaleontology, Vol. 43, No. 1-2, 2001, pp. 1-25.

[31] J. O. Herrle, J. Pross, O. Friedrich and C. Hemleben, "Short-Term Environmental Changes in the Cretaceous Tethyan Ocean: Micropalaeontological Evidence from the Early Albian Oceanic Anoxic Event 1b,” Terra Nova, Vol. 15, No. 1, 2003, pp. 14-19. doi:10.1046/j.1365-3121.2003.00448.x

[32] J. O. Herrle, J. Pross, O. Friedrich, P. Kössler and C. Hemleben, "Forcing Mechanisms for Mid-Cretaceous Black Shale Formation: Evidence from the Upper Aptian and Lower Albian of the Vocontian Basin (SE France)," $\mathrm{Pa}$ laeogeography, Palaeoclimatology, Palaeoecology, Vol. 190, 2003, pp. 399-426. doi:10.1016/S0031-0182(02)00616-8

[33] D. Bukry, “Coccolith and Silicoflagellate Stratigraphy, Tasman Sea and Southwestern Pacific Ocean, Deep Sea Drilling Project Leg 21,” Deep Sea Drilling Project Initial Reports, Vol. 21, 1973, pp. 885-893. 


\section{doi:10.2973/dsdp.proc.21.127.1973}

[34] D. K. Watkins, "Upper Cretaceous Nannofossils from Leg 120, Kerguelen Plateau, Southern Ocean,” Proceedings of the Ocean Drilling Program, Scientific Results, Vol. 120, 1992. pp. 343-370.

[35] B. T. Huber and D. K. Watkins, "Biogeography of Campanian-Maastrichtian Calcareous Plankton in the Region of the Southern Ocean: Paleogeographic and Paleoclimatic Simplications,” In: J. P. Kennett and D. A. Warnke, Eds., The Antarctic Paleoenvironment: A Perspective on Global Change, American Geophysical Union (AGU), Washington DC, 1992, pp. 31-60.

[36] M. Black and B. Barnes, "The Structure of Coccoliths from the English Chalk," Geological Magazine, Vol. 96, No. 5, 1959, pp. 321-328. doi:10.1017/S0016756800062294

[37] K. Perch-Nielsen, "Der Feinbau und die Klassifikation der Coccolithen aus dem Maastrichtien von Danemark," K. Dan. Vidensk. Selsk. Biol. Skr., Vol. 16, No. 1, 1968, pp. 1-96.

[38] G. Deflandre, "Sur les Nannofossiles Calcaire et leur Systematique,” Rev. Micropaleontol., Vol. 2, 1959, pp.
127-152.

[39] V. N. Vekshina, "Coccolithophoridae of the Maastrichtian Deposits of the West Siberian Lowlands," SNIIGGIMS, Vol. 2, 1959, pp. 56-77.

[40] A. D. Arkhangelsky, "Upper Cretaceous Deposits of East European Russia,” Materialien zur Geologie Russlands, Vol. 25, 1912, pp. 1-631.

[41] G. Deflandre and C. Fert, “Observation sur les Coccolithophorides Actuels et Fossils en Microscopie Ordinaire et Electronique,” Annales de Paleontologie, Vol. 40, 1954, pp. 115-176.

[42] E. Martini, "Nannoplankton aus dem Tertiar und der Obersten Kreide von SW-Frankreich,” Senckenbergiana Lethaea, Vol. 42, 1961, pp. 1-32.

[43] H. Stradner, "New Contributions to Mesozoic Stratigraphy by Means of Nannofossils," Proceedings of the 6th World Petroleum Congress, Frankfurt am Main, 19-26 June 1963, pp. 1-16.

[44] M. N. Bramlette and E. Martini, "The Great Change in Calcareous Nannoplankton Fossils between the Maastrichtien von Danemark,” K. Dan. Vidensk. Selsk. Biol. Skr., Vol. 16, No. 1, 1964, pp. 1-96.

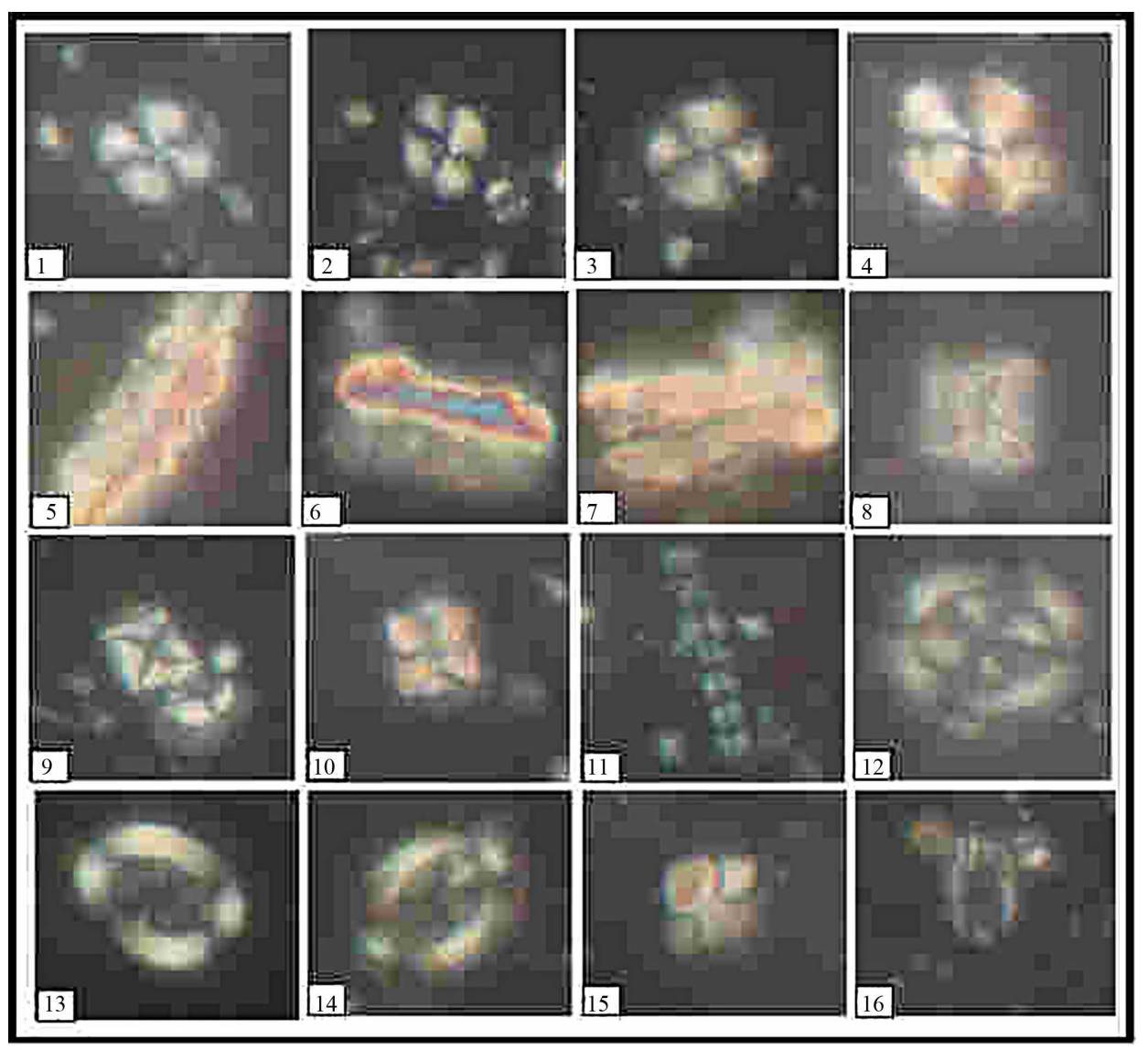

Plate 1. All figures $\times 1250$. $(1,2,3)$ : Watznaueria barnesae [36], 1 sample No. 1, 2 sample No. 34, 3 sample No. 43; (4): Cyclagelosphaera reinhardtii [37], sample No. 48; (5, 6, 7): Lucianorhabdus cayeuxii [38], 5 sample No. 21, 6 sample No. 22, 7 sample No. 23; (8, 9, 10): Micula decussata [39], 8 sample No. 34, 9 sample No. 43, 10 sample No. 48; (11): Microrhabdulus decoratus [38], sample No. 22; $(12,13,14)$ : Arkhangelskiella cymbiformis [39], 12 sample No. 19, 13 sample No. 22, 14 sample No. 50; (15): Calculites obscurus [38], sample No. 22; (16): Cribrosphaerella ehrenbergii [40], sample No. 48. 


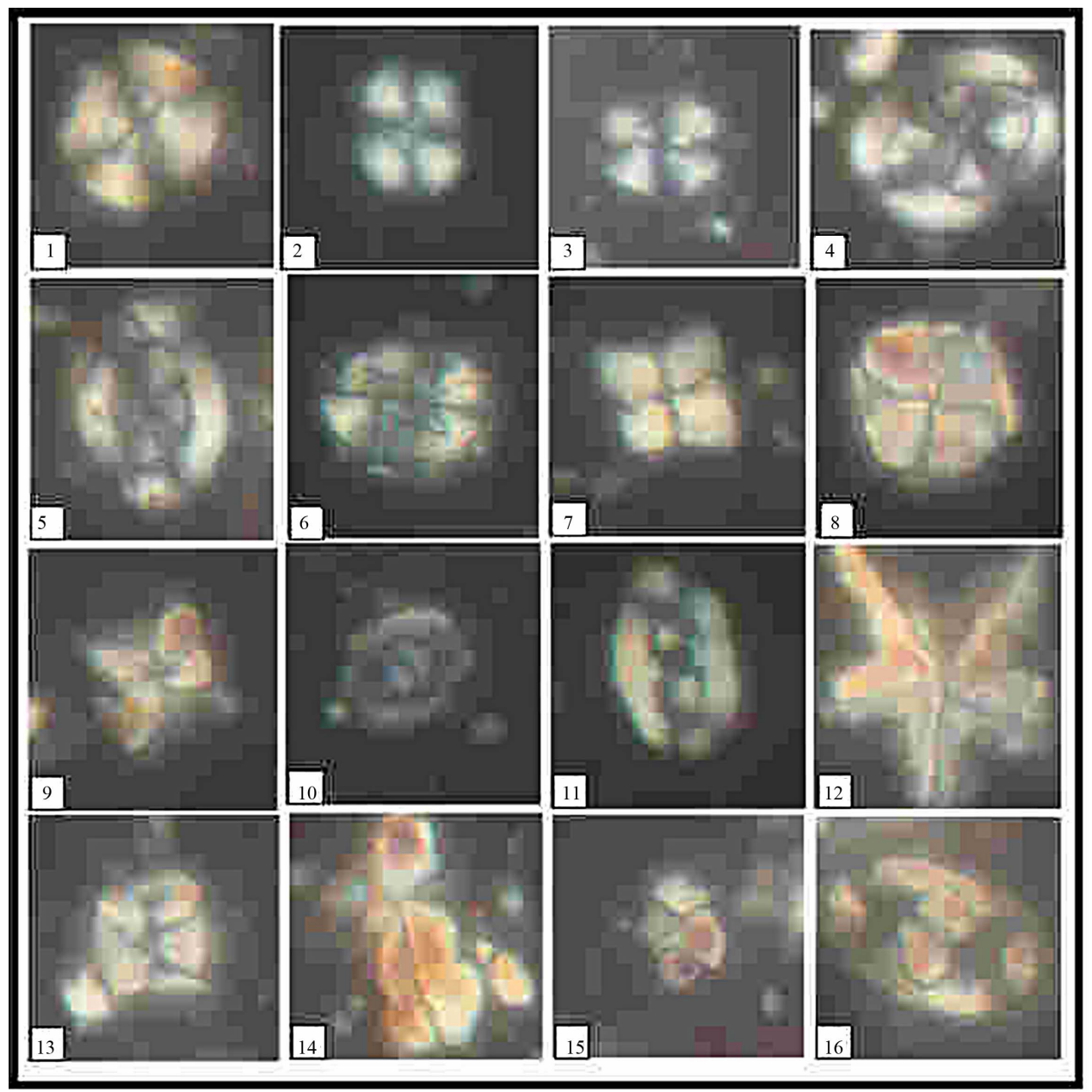

Plate 2. All figures $\times 1250$. (1): Cyclagelosphaera reinhardtii [37], sample No. 1; (2, 3): Watznaueria barnesae [36], 2 sample No. 21, 3 sample No. 48; $(4,5)$ : Arkhangelskiella cymbiformis [39], 4 sample No. 43, 5 sample No. 50; (6): Eiffellithus turrisiefelii [41], sample No. 37; $(7,8):$ Micula murus [42], 7 sample No. 1, 8 sample No. 37; $(9,13):$ Micula decussata [39], 9 sample No. 21, 13 sample No. 34; (10): Glaukolithus diplogrammus [41], sample No. 19; (11): Rhagodiscus angustus [43], sample No. 22; (12): Micrantholithus vesper [41], sample No. 43; (14): Lucianorhabdus cayeuxii [38], sample No. 21; (15): Calculites obscurus [38], sample No. 22; (16): Zeugrhabdotus pseudanthophorus [44], sample No. 23. 